\title{
Inhibition by Atrial and Brain Natriuretic Peptides of Endothelin-1 Secretion after Stimulation with Angiotensin II and Thrombin of Cultured Human Endothelial Cells
}

\author{
Masakazu Kohno, Kenichi Yasunari, Koji Yokokawa, Koh-ichi Murakawa, Takeshi Horio, and Tadanao Takeda \\ With the technical assistance of Machiko Johchi \\ First Department of Internal Medicine, Osaka City University Medical School, Abeno-ku, Osaka 545, Japan
}

\begin{abstract}
We examined the inhibition by atrial natriuretic peptide (ANP) and brain natriuretic peptide (BNP) of endothelin-1 secretion stimulated by angiotensin II (ANGII) and thrombin using cultured human umbilical-vein endothelial cells. ANGII and thrombin dose-dependently stimulated immunoreactive (ir) endothelin-1 secretion. Human ANP(1-28) and human BNP-32 both inhibited such secretion in a dose-dependent way. Inhibition of this secretion by ANP and BNP was paralleled by an increase in the level of cyclic guanosine 5'-monophosphate (GMP). The addition of a cyclic GMP analogue, 8-bromo cyclic GMP, reduced this stimulated secretion. Rat ANP(5-25) was weaker than human ANP(1-28) at inhibiting ir-endothelin1 secretion and increasing cyclic GMP in the cells. ir-Endothelin-1 in the medium consisted of two components separated by high pressure liquid chromatography; the major one corresponded to endothelin-1(1-21) and the minor one corresponded to big endothelin-1(1-38). Treatment with ANP and BNP did not affect this profile. These findings suggest that human ANP and BNP inhibit endothelin-1 secretion stimulated by ANGII and thrombin in these cells through a cyclic GMP-dependent process. Taken together with endothelin stimulation of ANP and BNP secretion from the heart, our results suggest the existence of a cardiac-endothelium feedback. (J. Clin. Invest. 1991. 87:1999-2004.) Key words: ANP • BNP • endothelin • cyclic GMP
\end{abstract}

\section{Introduction}

Atrial natriuretic peptide (ANP) ${ }^{1}$ is a diuretic, natriuretic, and vasodilatory peptide hormone originally isolated from mammalian hearts $(1,2)$. A novel natriuretic peptide, brain natriuretic peptide (BNP), has been identified in the porcine brain (3), and later isolated from the mammalian heart (4). BNP has diuretic, natriuretic, and hypotensive effects, and also relaxes the chick rectum, as ANP does (3). Recently, two types of human receptor for natriuretic peptides, ANP-A and ANP-B receptors possessing the guanylate cyclase domain, were deter-

Address correspondence and reprint requests to Dr. Masakazu Kohno, First Department of Internal Medicine, Osaka City University Medical School, 1-5-7 Asahi-machi, Abeno-ku, Osaka 545, Japan.

Received for publication 12 September 1990 and in revised form 4 February 1991.

1. Abbreviations used in this paper: ANP, BNP, atrial, brain natriuretic peptide; ANGII, angiotensin II; GMP, guanosine 5'-monophosphate; HUVEC, human umbilical-vein endothelial cells; IBMX, 3-isobutyl-1-methylxanthine; ir, immunoreactive.

J. Clin. Invest.

(c) The American Society for Clinical Investigation, Inc. $0021-9738 / 91 / 06 / 1999 / 06 \$ 2.00$

Volume 87, June 1991, 1999-2004 mined by molecular cloning (5). The ANP-B receptor is preferentially activated by BNP rather than ANP, whereas the ANP-A receptor responds similarly to both natriuretic peptides (5). Therefore, both ANP and BNP may regulate vascular tonus and fluid homeostasis as cardiac hormones.

Endothelin-1, a peptide of 21 amino acids that is produced by vascular endothelial cells, is a contractile agent (6-9). This peptide is present in human plasma $(10,11)$ and is at high levels in patients with acute myocardial infarction $(12,13)$, uremia (14), or severe hypertension (15). This peptide is a secretagogue for ANP and BNP in atria (16-19). Cultured endothelial cells (20-22) and aortic strips with an intact endothelium $(23,24)$ secrete immunoreactive (ir) endothelin-1 in a time-dependent way. On the other hand, a potent vasoconstrictor, angiotensin II (ANGII), and a clotting enzyme, thrombin, stimulate endothelin-1 secretion from cultured endothelial cells $(20,21,23$, 24). So we examined the effects of human ANP(1-28), the major circulating form of ANP, human ANP(5-28), rat ANP(5$25)$, which is weaker biologically than human $\operatorname{ANP}(1-28)$, and human BNP-32, the major storage form of BNP in the human atrium (25), on the endothelin-1 secretory response to ANGII and thrombin in cultured human umbilical-vein endothelial cells (HUVEC).

\section{Methods}

Endothelial cell culture. HUVEC were obtained by treatment of umbilical veins with collagenase and were grown to confluence in medium 199 , which contained $20 \%$ fetal calf serum, endothelial cell growth supplement $(20 \mu \mathrm{g} / \mathrm{ml})$, penicillin $(100 \mu \mathrm{g} / \mathrm{ml})$, and streptomycin $(50$ $\mu \mathrm{g} / \mathrm{ml}$ ). Endothelial cells were identified by their "cobblestone" appearance by phase contrast microscopy and by immunofluorescence when stained for factor VIII antigen. Smooth muscle cells contamination was less than $0.1 \%$. Cultures were maintained at $37^{\circ} \mathrm{C}$ with atmospheric air and $5 \% \mathrm{CO}_{2}$, and subculture was carried out after the treatment with Versene ${ }^{\oplus}$ (Gibco Laboratories, Grand Island, NY) and then trypsin.

Materials and supplies. ANGII, 8-bromo cyclic guanosine 5'-monophosphate (GMP), 3-isobutyl-1-methylxanthine (IBMX), and the endothelial cell growth supplement were purchased from Sigma Chemical Co. (St. Louis, MO). Purified human thrombin was the gift of Sankyo Co. (Tokyo, Japan). Medium 199, trypsin, Versene ${ }^{\oplus}$, and FCS were purchased from Gibco Laboratories (Grand Island, NY). Flasks were purchased from Becton Dickinson \& Co. (Oxnard, CA). Synthetic endothelin-1, endothelin-2, endothelin-3, big endothelin-1 (human, $1-38$ ), somatostatin, $\beta$-endorphin, human secretin, and synthetic human ANP(1-28) and -(5-28), rat ANP (5-25), and human BNP-32 were purchased from Peptide Institute, Inc. (Osaka, Japan). Endothelin-1 antiserum was purchased from Peninsula Laboratories, Inc. (Belmont, CA). ${ }^{125}$ I-endothelin-1 was purchased from Amersham Japan Inc. (Tokyo, Japan). The cyclic GMP assay kit was purchased from Yamasa Shoyu Co., Ltd. (Chiba, Japan). All other materials were obtained as described previously (23).

Pharmacological treatment. Cells from passages 4 to 8 were used. The culture medium was removed and the cell monolayers were washed twice with serum-free medium 199. ANGII, thrombin, ANP, 
and BNP were dissolved in distilled water. Then, these agents were added to the medium except for the controls and the culture medium was incubated at $37^{\circ} \mathrm{C}$. All experiments were done with $4 \mathrm{ml}$ of serumfree medium 199. After the incubation, the medium was aspirated and centrifuged at $3,000 \mathrm{~g}$ for $10 \mathrm{~min}$, and the supernatant was collected and stored at $-80^{\circ} \mathrm{C}$ until radioimmunoassay. Serum-free medium 199 was used to avoid the presence of hormones and enzymes that could have masked the effects of the pharmacological agent added (26).

Extraction of ir-endothelin-1. ir-Endothelin-1 was extracted as previously described (23). Briefly, $1.5 \mathrm{ml}$ from each sample was diluted with $4 \mathrm{ml}$ of $4 \%$ acetic acid. After centrifugation, the solution was pumped at the rate of $1 \mathrm{ml} / \mathrm{min}$ through a Sep-Pak $\mathrm{C}_{18}$ cartridge (Millipore Corp., Milford, MA). After the cartridge was washed with $5 \mathrm{ml}$ of distilled water, the adsorbed peptides were eluted with $86 \%$ ethanol in $4 \%$ acetic acid. After evaporation of the eluate by a centrifugal evaporator (model RD-31; Yamato Scientific Co., Tokyo, Japan), the dry residue was dissolved in the assay buffer described below. The recovery rate was found by the addition of four different quantities of cold endothelin- $1(25,50,100$, and $500 \mathrm{pg} / \mathrm{ml})$ to serum-free medium 199 . Recovery was $67 \%$.

Radioimmunoassay of endothelin-1. The ir-endothelin-1 concentration was assayed with the use of endothelin-1 antiserum and ${ }^{125}$ I-endothelin-1 as a.tracer. This antibody reacts $100 \%$ with endothelin-1, and cross-reacts $84 \%$ with endothelin- $2,5 \%$ with endothelin-3, and $14 \%$ with big endothelin- 1 (human, 1-38). The antiserum did not crossreact with human ANP(1-28) or -(5-28), rat ANP(5-25), human BNP32 , somatostatin, $\beta$-endorphin, human secretin, ANGII, or vasopressin.

Radioimmunoassay was done in an assay buffer of $0.01 \mathrm{M}$ sodium phosphate, $\mathrm{pH} 7.4$, containing $0.05 \mathrm{M} \mathrm{NaCl}, 0.1 \%$ bovine serum albumin, $0.1 \%$ Nonidet NP-40, and $0.01 \% \mathrm{NaN}_{3}$ as described previously (23). In brief, rehydrated antiserum $(100 \mu \mathrm{l})$ was added to $100 \mu \mathrm{l}$ of the sample or $100 \mu \mathrm{l}$ of standard endothelin-1 dissolved in the assay buffer and the mixture was incubated for $24 \mathrm{~h}$ at $4^{\circ} \mathrm{C}$. Approximately 15,000 cpm of ${ }^{125}$ I-endothelin-1 was added to each reaction and incubated for an additional $24 \mathrm{~h}$. After this incubation, $100 \mu \mathrm{l}$ of diluted normal rabbit serum and $100 \mu$ lof diluted goat anti-rabbit immunoglobulin $G$ serum were added and the mixture was again incubated for $24 \mathrm{~h}$. After the third incubation, the precipitate was collected by centrifugation at $1,700 \mathrm{~g}$ for $30 \mathrm{~min}$. The supernatant was removed by aspiration and the pellet was counted for ${ }^{125} \mathrm{I}$ with a gamma counter. The interassay variation was $13 \%$ and the intraassay variation was $7 \%$.

ANP, BNP, thrombin, and ANGII did not interfere with the radioimmunoassay.

Reverse-phase HPLC. Reverse-phase HPLC was done with an octadecylsilica column $(4.6 \times 250 \mathrm{~mm}$; Gasukuro Kogyo, Inc., Tokyo, Japan) eluted with a linear gradient of acetonitrile from $33 \%$ to $51 \%$ in $0.09 \%$ trifluoroacetic acid and $0.01 \mathrm{M} \mathrm{NaCl}$ with the flow rate of 1 $\mathrm{ml} / \mathrm{min}$; as described previously (23), $0.5-\mathrm{ml}$ fractions were collected and assayed by radioimmunoassay. For chromatographic analysis of ir-endothelin-1, $30 \mathrm{ml}$ of pooled medium was separated and treated by reverse-phase HPLC.

Cyclic GMP measurement. After preincubation, the cell monolayers were washed twice with serum-free medium 199 and then stimulated for $30 \mathrm{~min}$ with different concentrations of ANP or BNP dissolved in medium 199 that contained $0.5 \mathrm{mM}$ IBMX reported previously (27). Rapid aspiration and the addition of $2 \mathrm{ml}$ of ice-cold $65 \%$ ethanol stopped the reaction. Cyclic GMP levels were found by radioimmunoassay done with the cyclic GMP assay kit.

Calculations and statistical analysis. The statistical significance of differences in the results was evaluated by an analysis of variance, and $P$ values were calculated by Scheffe's method (28). Values were expressed as means $\pm \mathrm{SD}$.

\section{Results}

Effects of ANGII and thrombin on ir-endothelin-1 secretion by HUVEC. Confluent cultured cells secreted ir-endothelin-1 into
Table I. Effects of ANGII and Thrombin on ir-Endothelin-1 Secretion in Cultured HUVEC

\begin{tabular}{lllc}
\hline & \multicolumn{3}{c}{ ir-Endothelin-1 level (pg/5 $\times 10^{5}$ cells) } \\
with incubation of: \\
\hline & $2 h$ & $4 h$ & $6 h$ \\
Baseline & $10 \pm 3$ & $18 \pm 5$ & $32 \pm 7$ \\
ANGII $10^{-9} \mathrm{M}$ & $14 \pm 3$ & $30 \pm 4$ & $41 \pm 9$ \\
$10^{-8} \mathrm{M}$ & $26 \pm 3^{*}$ & $47 \pm 6^{*}$ & $54 \pm 6^{*}$ \\
$10^{-7} \mathrm{M}$ & $32 \pm 6^{*}$ & $70 \pm 9^{*}$ & $83 \pm 8^{*}$ \\
Baseline & $12 \pm 4$ & $20 \pm 5$ & $31 \pm 5$ \\
Thrombin $0.1 \mathrm{U} / \mathrm{ml}$ & $21 \pm 7$ & $48 \pm 9^{*}$ & $64 \pm 7^{*}$ \\
$1.0 \mathrm{U} / \mathrm{ml}$ & $38 \pm 8^{*}$ & $69 \pm 6^{*}$ & $91 \pm 10^{*}$ \\
$10 \mathrm{U} / \mathrm{ml}$ & $41 \pm 5^{*}$ & $88 \pm 10^{*}$ & $107 \pm 12^{*}$ \\
\hline
\end{tabular}

Each value is the mean \pm SD of assays made of six cell cultures. Each assay was done in duplicate. ${ }^{*}$ Significant difference compared with baseline level $(P<0.05)$.

the culture medium in a time-dependent way. The effects of ANGII and thrombin on ir-endothelin-1 secretion were dose dependent (Table I). ir-Endothelin-1 secretion by ANGII and thrombin increased during $4 \mathrm{~h}$ of incubation and, thereafter, the rate of increase slightly declined. Therefore, later experiments about ir-endothelin- 1 secretion were done with cells incubated for $4 \mathrm{~h}$.

Effects of ANP and BNP on ir-endothelin-1 secretion before and after stimulation with ANGII and on cellular cyclic GMP levels. Neither ANP nor BNP significantly decreased spontaneous ir-endothelin-1 secretion between $10^{-10}$ and $10^{-6} \mathrm{M}$ (Table II).

Fig. $1 A$ shows the effects of human ANP(1-28) and -(5-28), rat ANP(5-25), and human BNP-32 on ir-endothelin-1 secretion by cultured HUVEC treated with $10^{-8} \mathrm{M}$ ANGII. Human ANP(1-28) and human BNP-32 inhibited the secretion of irendothelin- 1 in a dose-dependent way between $10^{-10}$ and $10^{-6}$ M. Human ANP(5-28) also inhibited such secretion, but its effect was somewhat less. In cells stimulated with ANGII, in parallel with the inhibition of ir-endothelin-1 secretion, cellular cyclic GMP increased with treatment of the cells with human ANP(1-28) or human BNP-32 (Fig. 1 B). Human ANP(5-28) also increased cyclic GMP levels in the cells, although not as much as human ANP(1-28) did. Rat ANP(5-25) was much weaker than those peptides at inhibiting ir-endothelin-1 secretion (Fig. $1 \mathrm{~A}$ ) and also much weaker at increasing cyclic GMP (Fig. $1 B$ ).

Table II. Effects of Human ANP (1-28) and BNP-32 on Spontaneous Secretion of ir-Endothelin-1 by Cultured HUVEC

\begin{tabular}{lcccc}
\hline & \multicolumn{4}{c}{ ir-Endothelin-1 level $\left(\mathrm{pg} / 4 \mathrm{~h}\right.$ per $5 \times 10^{5}$ cells) at peptide } \\
& \multicolumn{4}{c}{ concentration of: } \\
\cline { 2 - 5 } & 0 & $10^{-10}$ & $10^{-8}$ & $10^{-6}$ \\
\hline ANP (1-28) & $17 \pm 6$ & $19 \pm 6$ & $18 \pm 6$ & $14 \pm 8$ \\
BNP-32 & $17 \pm 5$ & $18 \pm 4$ & $16 \pm 6$ & $15 \pm 7$ \\
\hline
\end{tabular}

Cells were exposed to different concentrations of human ANP (1-28) or BNP-32 for $4 \mathrm{~h}$ at $37^{\circ} \mathrm{C}$. Each point represents the mean of six measurements. 

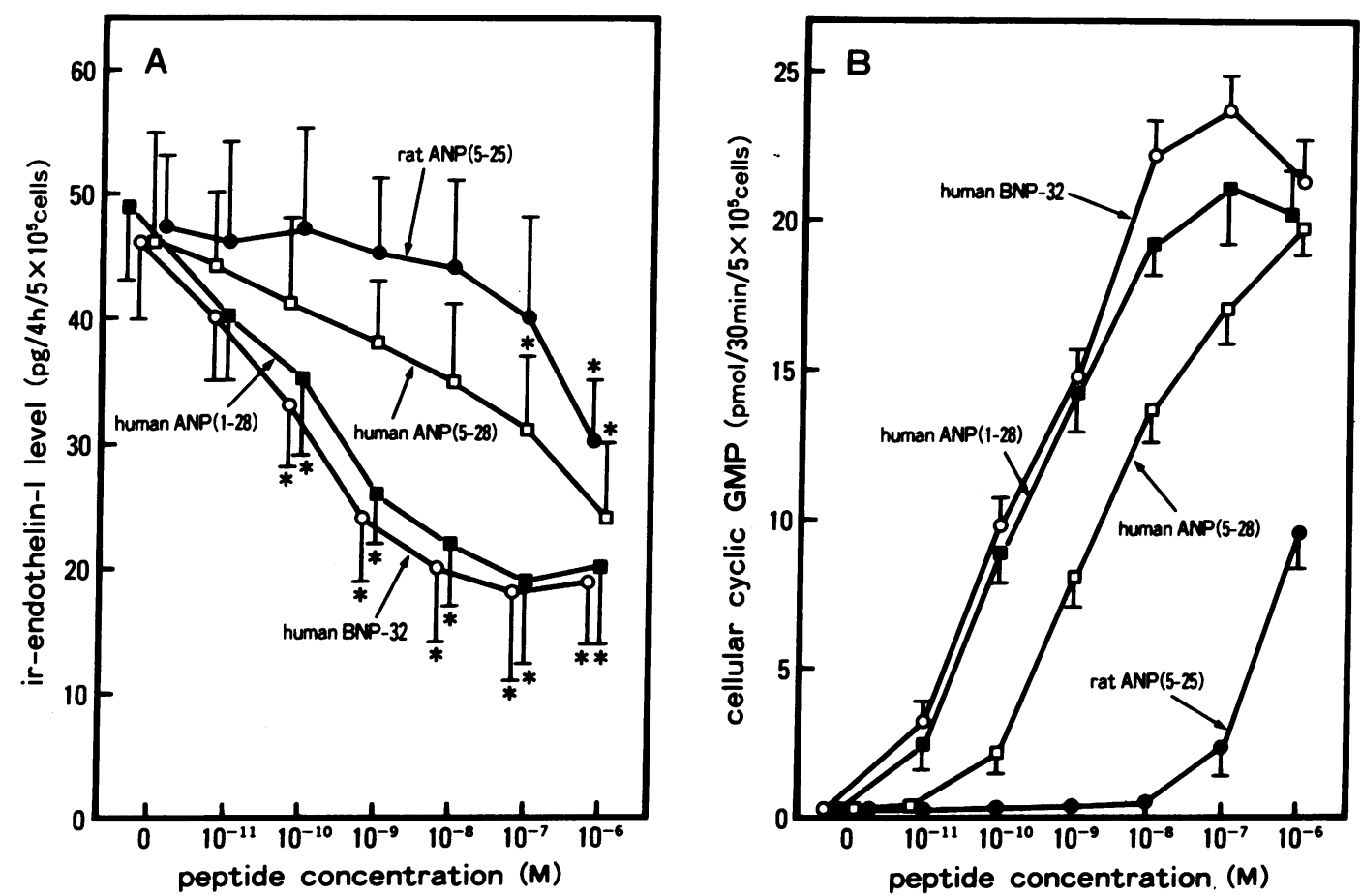

Figure 1. (A) Effects of ANP and BNP on ir-endothelin-1 secretion from cultured HUVEC stimulated with $10^{-8} \mathrm{M}$ ANGII. Cells were exposed to

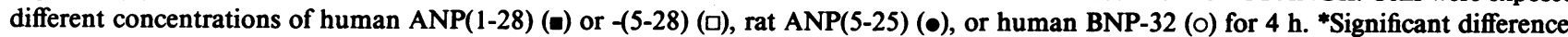
compared with values when neither ANP nor BNP was added $(P<0.05)$. $(B)$ Effects of ANP and BNP on cellular cyclic GMP level in cells

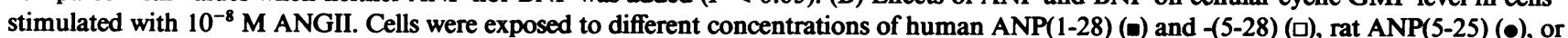
human BNP-32 (O) for $30 \mathrm{~min}$ in the presence of $0.5 \mathrm{mM}$ 3-isobutyl-1-methylxanthine. Each point is the mean of six measurements.
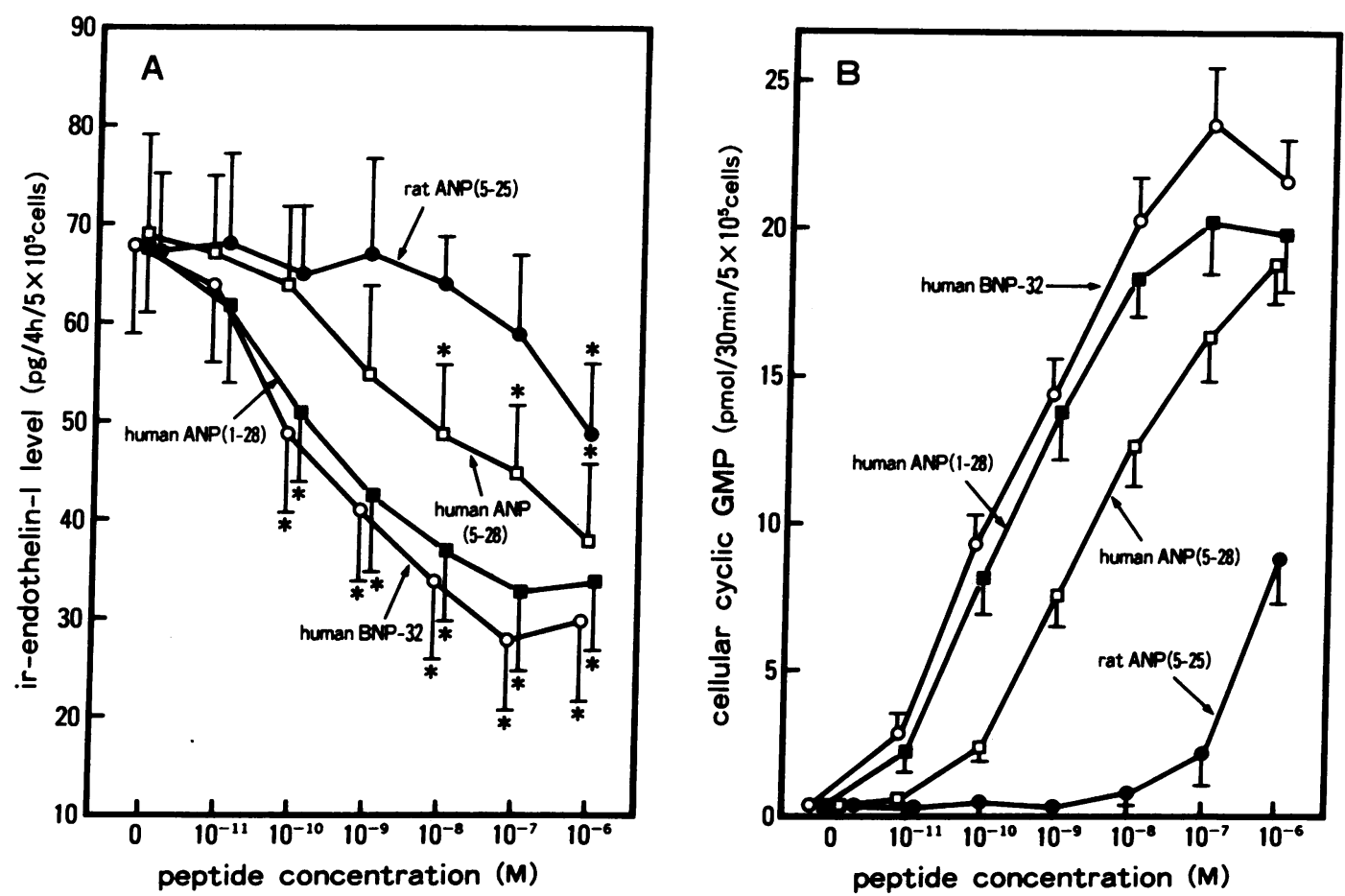

Figure 2. $(A)$ Effects of ANP and BNP on ir-endothelin-1 secretion from cultured HUVEC stimulated with $1.0 \mathrm{U} / \mathrm{ml}$ thrombin. Cells were

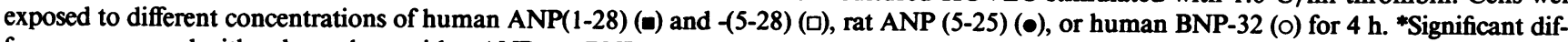
ference compared with values when neither ANP nor BNP was added $(P<0.05)$. (B) Effects of ANP and BNP on cellular cyclic GMP level in cells stimulated with $1.0 \mathrm{U} / \mathrm{ml}$ thrombin. Cells were exposed to different concentrations of human ANP(1-28) ( $(\bullet)$ and $-(5-28)(\square)$, rat ANP(5-25) $(\bullet)$, or human BNP-32 (o) for $30 \mathrm{~min}$ in the presence of $0.5 \mathrm{mM}$ 3-isobutyl-1-methylxanthine. Each point is the mean of six measurements. 
Effects of ANP and BNP on ir-endothelin-1 secretion after stimulation with thrombin and on cellular cyclic GMP levels. Fig. $2 A$ shows the effects of human ANP(1-28) and -(5-28), rat ANP(5-25), and human BNP-32 on ir-endothelin-1 secretion by cultured HUVEC treated with $1.0 \mathrm{U} / \mathrm{mL}$ thrombin. Effects of ANP and BNP on ir-endothelin-1 secretion after stimulation with thrombin was essentially the same as that after stimulation with ANGII. Human ANP(1-28) and human BNP-32 inhibited the secretion of ir-endothelin- 1 in a dose-dependent way between $10^{-10}$ and $10^{-6} \mathrm{M}$. Human ANP(5-28) also inhibited such secretion, but its effect was somewhat less.

In cells stimulated with thrombin, in parallel with the inhibition of ir-endothelin-1 secretion, cellular cyclic GMP increased with treatment of the cells with human ANP(1-28) or human BNP-32 (Fig. 2 B). Human ANP(5-28) also increased cyclic GMP levels although not as much as human ANP(1-28) did. Rat ANP(5-25) was much weaker than those peptides at inhibiting ir-endothelin-1 secretion (Fig. $2 A$ ) and also much weaker at increasing cyclic GMP (Fig. $2 \mathrm{~B}$ ).

HPLC of ir-endothelin-1 in extracts of culture medium treated with ANP or BNP. Elution profiles of extracts from control culture medium, medium treated with $10^{-8} \mathrm{M}$ ANGII, and medium treated with human ANP(1-28) or human BNP32 in addition to $10^{-8} \mathrm{M}$ ANGII by reverse-phase HPLC are shown in Fig. 3. Profiles of extracts from control culture medium, medium treated with $1.0 \mathrm{U} / \mathrm{ml}$ thrombin, and medium treated with human ANP(1-28) and human BNP-32 in addition to $1.0 \mathrm{U} / \mathrm{ml}$ thrombin are shown in Fig. 4. Two components of ir-endothelin-1 were observed, a major component eluted in the position of standard endothelin-1 (1-21) and the minor component eluted in the position of big endothelin- 1 (human, 1-38). ANGII, thrombin, human ANP(1-28), and human BNP-32 did not affect this pattern of two peaks.

Effect of a cyclic GMP analogue on ir-endothelin-1 secretion after stimulation with ANGII and thrombin. To elucidate whether the inhibitory effect of ANP and BNP on the ir-en-

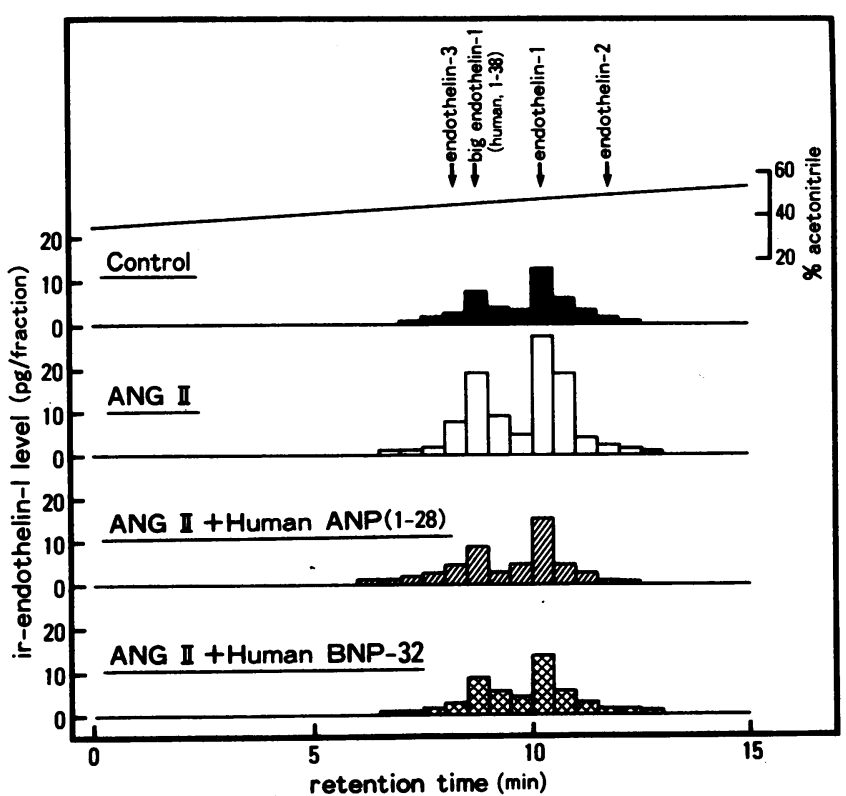

Figure 3. Reverse-phase HPLC of ir-endothelin-1 in extracts from control culture medium, medium treated with ANGII, and medium treated with ANP(1-28), or BNP-32, in addition to ANGII. The elution positions of standard endothelin-1, endothelin-2, endothelin-3, and big endothelin-1 (human, 1-38) are shown by the arrows.

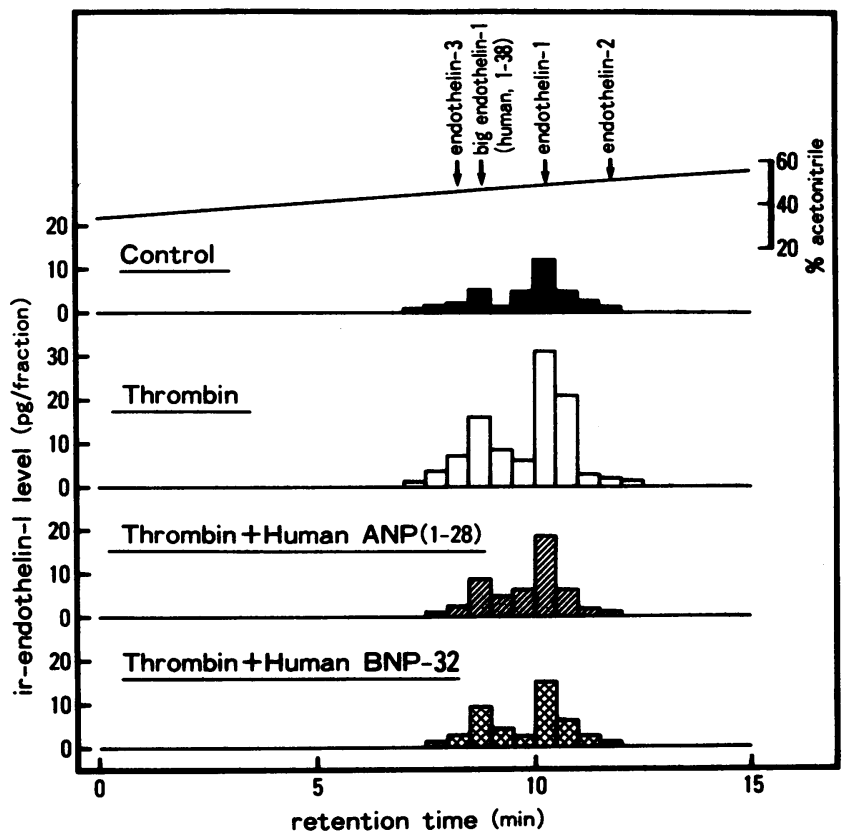

Figure 4. Reverse-phase HPLC of ir-endothelin-1 in extracts from control culture medium, medium treated with thrombin, and medium treated with ANP(1-28), or BNP-32 in addition to thrombin. The elution positions of standard endothelin-1, endothelin-2, endothelin-3, and big endothelin-1 (human, 1-38) are shown by the arrows.

dothelin-1 secretion after stimulation with ANGII and thrombin is causally linked to the increase in cellular cyclic GMP, we examined the effect of a cyclic GMP analogue, 8-bromo cyclic GMP, on secretion. The addition of this analogue at $10^{-5}$ or $10^{-4} \mathrm{M}$ reduced the ir-endothelin- 1 secretion after stimulation with ANGII and thrombin by $25-40 \%$ (Fig. $5, A$ and $B$ ).

\section{Discussion}

ANP is originally isolated from the mammalian heart $(1,2)$. Recently, a novel natriuretic peptide has been identified in the porcine brain, (3) designated as BNP, and has been subse-
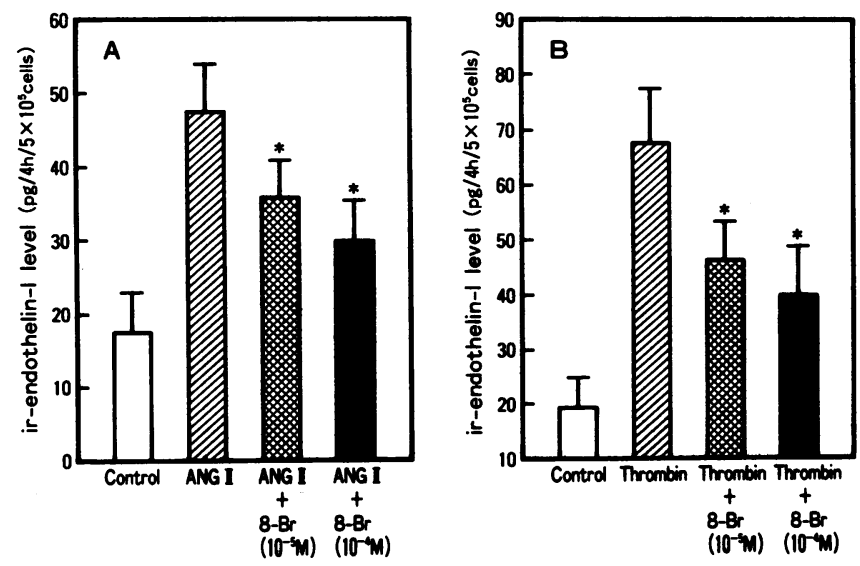

Figure 5. Effect of 8-bromo cyclic GMP $\left(10^{-5}\right.$ or $\left.10^{4} \mathrm{M}\right)$ on ir-endothelin-1 secretion from cultured HUVEC stimulated with ANGII $(A)$ and thrombin $(B)$. Cells were exposed to $10^{-5}$ or $10^{-4} \mathrm{M} 8$-bromo cyclic GMP for $4 \mathrm{~h}$. Each point is the mean of six measurements. 8-Br, 8-bromo cyclic GMP. *Significant effect of 8-bromo cyclic GMP on the response to ANGII or thrombin $(P<0.05)$. 
quently isolated from human (25), rat (29), and porcine heart (4). It is suggested that both ANP and BNP are secreted from the heart and play a role in the regulation of vascular tonus and fluid homeostasis. Endothelin-1 has been shown to be a secretagogue for ANP and BNP in atrial myocytes (16-19). Here, we confirmed that ANGII and thrombin dose-dependently stimulate ir-endothelin-1 secretion in cultured HUVEC, and found that human ANP (1-28), the major circulating form of ANP, strongly inhibited the endothelin-1 secretion stimulated by ANGII and thrombin in cultured HUVEC. Half-maximal inhibition could be observed at $10^{-10} \mathrm{M}$ human ANP(1-28). This concentration is higher than the normal concentration of plasma ANP in humans and rats (30-33). However, when the volume of intravascular fluid increased $(30,31,34,35)$, or during exercise $(36,37)$, ANP levels increased to $10^{-10} \mathrm{M}$. Therefore, ANP is likely to regulate the secretion of endothelin-1 caused by a potent vasoconstrictor, ANGII, and a clotting enzyme, thrombin. Human ANP(5-28), which is not the major circulating form of ANP, also inhibited such secretion, but its effect was somewhat less. On the other hand, rat ANP(5-25), which is weaker biologically than rat ANP(1-28) and human ANP(1-28), significantly inhibited such secretion only at the concentration at $10^{-6} \mathrm{M}$.

Human BNP-32 strongly inhibited the endothelin-1 secretion stimulated by ANGII and thrombin. Half-maximal inhibition could be observed at $10^{-10} \mathrm{M}$. This concentration is much higher than the normal circulating BNP levels $\left(10^{-12} \mathrm{M}\right)(38)$. The change in circulating BNP with volume loading seems to be greater than that of ANP. Plasma BNP levels increase to $10^{-10} \mathrm{M}$ in patients with severe congestive heart failure (38). Therefore, circulating BNP may also inhibit the endothelin-1 secretion stimulated by ANGII and thrombin.

We have obtained three pieces of evidence for a causal link between cyclic GMP production and inhibition of endothelin1 secretion by ANP and BNP in cells stimulated with ANGII and thrombin. First, human ANP and BNP increased cyclic GMP levels, and these effects parallel the inhibition of endothelin-1 secretion. Second, a cyclic GMP analogue reduced ANGII- and thrombin-stimulated ir-endothelin-1 secretion. Third, rat ANP(5-25) had weaker effects than human ANP(128 ) or BNP-32 in inhibiting ir-endothelin-1 secretion and also in increasing cyclic GMP in the cells stimulated with ANGII and thrombin. These results suggest that ANP and BNP inhibit ANGII- and thrombin-stimulated endothelin-1 secretion through a cyclic GMP-dependent process. Although the exact cellular mechanism remains to be clarified, the findings that ANP and BNP failed to inhibit basal endothelin-1 secretion and strongly inhibited the stimulated endothelin-1 secretion with ANGII and thrombin may suggest that the observed effects of ANP and BNP are proximal to endothelin-1 gene expression.

Circulating ANP or BNP may suppress excess secretion of endothelin-1 caused by activation of the renin-angiotensin system and of the coagulation cascade. Endothelin-1 stimulates aldosterone secretion (39). Therefore, ANP may also suppress the overproduction of aldosterone not only directly (40) but also through the inhibition of endothelin-1 secretion.

Our results suggest that there may be a cardiac-endothelium feedback. Such a local paracrine inhibitory effect of ANP and BNP seems plausible, and is consistent with the classic concept of negative feedback. Reaction between ANP or BNP and endothelin may occur in the regulation of vascular tonus and fluid homeostasis.

\section{Acknowledgments}

This study was supported by a Grant-in-Aid for Scientific Research (6148210) from the Ministry of Education, Science, and Culture, Japan.

\section{References}

1. Kangawa, K., and H. Matsuo. 1984. Purification and complete amino acid sequence of $\alpha$-human atrial natriuretic polypeptide ( $\alpha$-hANP). Biochem. Biophys. Res. Commun. 118:131-139.

2. De Bold, A. J. 1985. Atrial natriuretic factor: a hormone produced by the heart. Science (Wash. DC). 230:767-770.

3. Sudoh, T., K. Kangawa, N. Minamino, and H. Matsuo. 1988. A new natriuretic peptide in porcine brain. Nature (Lond.). 332:78-81.

4. Minamino, N., M. Aburaya, S. Ueda, K. Kangawa, and H. Matsuo. 1988 The presence of brain natriuretic peptide of 12,000 daltons in porcine heart. Biochem. Biophys. Res. Commun. 155:740-746.

5. Chang, M. S., D. G. Lowe, M. Lewis, R. Hellmiss, E. Chen, and D. V. Gpeddel. 1989. Differential activation by atrial and brain natriuretic peptides of two different receptor guanylate cyclases. Nature (Lond.). 341:68-72.

6. Hickey, K. A., G. Rubanyi, R. J. Paul, and R. F. Highsmith. 1985. Characterization of a coronary vasoconstrictor produced by cultured endothelial cells. Am. J. Physiol. 248:C550-C556.

7. Yanagisawa, M., H. Kurihara, S. Kimura, Y. Tomobe, M. Kabayashi, Y. Mitsui, Y. Yazaki, K. Goto, and T. Masaki. 1988. A novel potent vasoconstrictor peptide produced by vascular endothelial cells. Nature (Lond.). 332:411-415.

8. Yokokawa, K., M. Kohno, K. Murakawa, K. Yasunari, T. Horio, T. Inoue and T. Takeda. 1989. Acute effects of endothelin on renal hemodynamics and blood pressure in anesthetized rats. Am. J. Hypertens. 715-717.

9. Miller, W. L., M. M. Redfield, and J. C. Burnett, Jr. 1989. Integrated cardiac, renal, and endocrine actions of endothelin. J. Clin. Invest. 83:317-320.

10. Cernacek, P., and D. J. Stewart. 1989. Immunoreactive endothelin in human plasma: marked elevations in patients in cardiogenic shock. Biochem. Biophys. Res. Commun. 161:562-567.

11. Ando, K., Y. Hirata, M. Shichiri, T. Emori, and F. Marumo. 1989. Presence of immunoreactive endothelin in human plasma. FEBS (Fed. Eur. Biol. Soc.) Lett. 245:164-166.

12. Miyauchi, T., M. Yanagisawa, T. Tomizawa, Y. Sugishita, N. Suzuki, M. Fujino, R. Ajisaka, K. Goto, and T. Masaki. 1989. Increased plasma concentrations of endothelin-1 and big endothelin-1 in acute myocardial infarction. Lancet. ii:53-54.

13. Yasuda, M., M. Kohno, A. Tahara, H. Itagane, I. Toda, K. Akioka, M. Teragaki, H. Oku, K. Takeuchi, and T. Takeda. 1990. Circulating immunoreactive endothelin in ischemic heart disease. Am. Heart J. 199:801-806.

14. Koyama, H., T. Tabata, Y. Nishizawa, T. Inoue, H. Morii, and T. Yamaji. 1989. Plasma endothelin levels in patients with uraemia. Lancet. i:991-992.

15. Kohno, M., K. Yasunari, K. Murakawa, K. Yokokawa, T. Horio, T. Fukui, and T. Takeda. 1990. Plasma immunoreactive endothelin in essential hypertension. Am. J. Med. 88:614-618.

16. Fukuda, Y., Y. Hirata, H. Yoshimi, T. Kojima, Y. Kobayashi, M. Yanagisawa, and T. Masaki. 1988. Endothelin is a potent secretagogue for atrial natriuretic peptide in cultured rat atrial myocytes. Biochem. Biophys. Res. Commun. 155:167-172.

17. Winquist, R. J., A. L. Scott, and G. P. Vlasuk. 1989. Enhanced release of atrial natriuretic factor by endothelin in atria from hypertensive rats. Hypertension (Dallas). 14:111-114.

18. Kohno, M., K. Murakawa, T. Horio, N. Kurihara, K. Yokokawa, K. Yasunari, T. Fukui, and T. Takeda. 1990. Endothelin stimulates release of atrial natriuretic factor in anesthetized rats. Metabolism. 39:557-559.

19. Hirata, Y., Y. Fukuda and T. lida. 1990. Endothelin-1 stimulates secretion of atrial and brain natriuretic peptides from porcine cardiocytes and increases ANP messenger RNA levels in rat cardiocytes. J. Hypertens. 8 (Suppl 3):s92a. (Abstr.)

20. Emori, T., Y. Hirata, K. Ohta, M. Shichiri, and F. Marumo. 1989. Secretory mechanism of immunoreactive endothelin in cultured bovine endothelial cells. Biochem. Biophys. Res. Commun. 160:93-100.

21. Schini, V. B., H. Hendrickson, D. M. Heublein, J. C. Burnett, Jr., and P. M. Vanhoutte. 1989. Thrombin enhances the release of endothelin from cultured porcine aortic endothelial cells. Eur. J. Pharmacol. 165:333-334.

22. Kohno, M., K. Murakawa, K. Yokokawa, K. Yasunari, T. Horio, N. Kurihara, and T. Takeda. 1989. Production of endothelin by cultured porcine endothelial cells: modulation by adrenaline. J. Hypertens. 7 (Suppl 6):s130-s131.

23. Kohno, M., K. Yasunari, K. Murakawa, K. Yokokawa, T. Horio, T. Fukui, and T. Takeda. 1990. Release of immunoreactive endothelin from porcine aortic strips. Hypertension (Dallas). 15:718-723.

24. Boulanger, C., and T. F. Luscher. 1990. Release of endothelin from the porcine aorta. Inhibition by endothelium-derived nitric oxide. J. Clin. Invest. 85:587-590. 
25. Kambayashi, Y., K. Nakao, M. Mukoyama, Y. Saito, Y. Ogawa, S. Shiono, K. Inouye, N. Yoshida, and H. Imura. 1990. Isolation and sequence determination of human brain natriuretic peptide in human atrium. FEBS (Fed. Eur. Biol. Soc.) Lett. 259:341-345.

26. Barnes, D., and G. Sato. 1980. Methods for growth of cultured cells in serum-free medium. Anal. Biochem. 102:255-270.

27. Yasunari, K., M. Kohno, A. Balmforth, K. Murakawa, K. Yokokawa, N. Kurihara, and T. Takeda. 1989. Gluco-corticoid and dopamine-1 receptors on vascular smooth muscle cells. Hypertension (Dallas). 13:575-581.

28. Wallenstein, S., C. L. Zucker, and J. L. Fleiss. 1980. Some statistical methods useful in circulation research. Circ. Res. 47:1-9.

29. Nakao, K., H. Itoh, Y. Kambayashi, K. Hosoda, Y. Saito, T. Yamada, M. Mukoyama, H. Arai, G. Shirakami, S. Suga, M. Jougasaki, Y. Ogawa, K. Inoue, and H. Imura. 1990. Rat brain natriuretic peptide. Isolation from rat heart and tissue distribution. Hypertension (Dallas). 15:774-778.

30. Tanaka, I., K. S. Misono, and T. Inagami. 1984. Atrial natriuretic factor in rat hypothalamus, atria and plasma: determination by specific radioimmunoassay. Biochem. Biophys. Res. Commun. 124:663-668.

31. Lang, R. E., H. Tholken, D. Ganten, F. C. Luft, H. Ruskoaho, and T. Unger. 1985. Atrial natriuretic factor: a circulating hormone stimulated by volume loading. Nature (Lond.). 314:264-266.

32. Larose, P., S. Meloche, P. du Souich, A. Delean, and H. Ong. 1985. Radioimmunoassay of atrial natriuretic factor: human plasma levels. Biochem. Biophys. Res. Commun. 130:553-558.

33. Sugawara, A., K. Nakao, N. Morii, M. Sakamoto, M. Suda, M. Shimo- kura, Y. Kiso, M. Kihara, Y. Yamori, K. Nishimura, J. Soneda, T. Ban, and H. Imura. 1985. $\alpha$-Human atrial natriuretic polypeptide is released from the heart and circulates in the body. Biochem. Biophys. Res. Commun. 129:439-446.

34. Kohno, M., K. B. Clegg, and M. P. Sambhi. 1987. Effects of volume change on circulating immunoreactive atrial natriuretic factor in rats. Hypertension (Dallas). 10:171-175.

35. Burnett, J. C., Jr., P. C. Kao, D. C. Hu, D. W. Heser, D. Heublein, J. P. Granger, T. J. Opgenorth, and G. S. Reeder. 1986. Atrial natriuretic peptide elevation in congestive heart failure in the human. Science (Wash. DC). 231:1145-1147.

36. Nishikimi, T., M. Kohno, T. Matsuura, K. Akioka, M. Teragaki, M. Yasuda, H. Oku, K. Takeuchi, and T. Takeda. 1986. Effect of exercise on circulating atrial natriuretic polypeptide in valvular heart disease. Am. J. Cardiol. 58:1119-1120.

37. Kohno, M., K. Murakawa, N. Kurihara, and T. Takeda. 1987. Circulating atrial natriuretic peptides during exercise in patients with chronic respiratory failure. Chest. 92:769-770.

38. Mukoyama, M., K. Nakao, Y. Saito, Y. Ogawa, K. Hosoda, S. Suga, G. Shirakani, M. Jougasaki, and H. Imura. 1990. Human brain natriuretic peptide, a novel cardiac hormone. Lancet. 335:801-802.

39. Gomez-Sanchez, C. E., E. N. Cozza, M. F. Foecking, S. Chiou, and M. W. Ferris. 1990. Endothelin receptor subtypes and stimulation of aldosterone secretion. Hypertension (Dallas). 15:744-747.

40. Atarashi, K., P. J. Mulrow, R. Franco-Saenz, R. Snajdar, and J. Rapp. 1984. Inhibition of aldosterone production by an atrial extract. Science (Wash. DC). 224:992-994. 